\title{
MODEL POTENSI INDUSTRI KREATIF SKALA USAHA MIKRO KECIL DAN MENENGAH BERBASIS SISTEM INFORMASI GEOGRAFIS DI KABUPATEN BANDUNG BARAT DALAM UPAYA MENINGKATKAN PENDAPATAN
}

\author{
Rahma Wahdiniwaty ${ }^{1}$, Deden A. Wahab Sya'roni ${ }^{2}$, Eko Budi Setiawan ${ }^{3}$ \\ ${ }^{1,2}$ Program Studi Magister Manajemen, Universitas Komputer Indonesia, Jl. Dipatiukur 112-114, Bandung, Indonesia \\ ${ }^{3}$ Teknik Informatika, Universitas Komputer Indonesia, Jl. Dipatiukur 112-114, Bandung, Indonesia \\ E-mail: zardien@yahoo.com; wahabs_den@yahoo.com; ekobudisetiawan@ymail.com
}

\begin{abstract}
Abstrak: Kurangnya informasi kepada masyarakat umum tentang potensi industri kreatif pada skala UMKM yang dimiliki di Kabupaten Bandung Barat mengakibatkan pertumbuhan ekonomi kurang meningkat secara signifikan sehingga peningkatan pendapatan bagi para UMKM sulit berkembang. Dengan demikian, kebutuhan sistem informasi sangat diperlukan bagi industri kreatif skala UMKM di Kabupaten Bandung. Dengan persebaran informasi mengenai produk industri kreatif pada skala UMKM dengan memanfaatkan Sistem Informasi Geografis (SIG), maka diharapkan peningkatan skala usaha dan produktivitas usaha di sektor industri kreatif skala UMKM akan berkembang dan meningkat. Penelitian tahun pertama ini mempunyai hasil output berupa profil UMKM Kabupaten Bandung Barat, profil potensi pelaku usaha industri kreatif UMKM, profil potensi usaha industri kreatif dan model rancangan untuk penyebaran informasi potensi industri kreatif.
\end{abstract}

Kata kunci: Industri kreatif; UMKM; persebaran informasi; Sistem Informasi Geografis SIG.

\begin{abstract}
Lack of information to the public about the potential of the creative industries on a scale which is owned UMKM West Bandung regency result less economic growth increased significantly thus increasing revenue for the SMEs to grow. Thus, the need for information systems is indispensable for the creative industry in Bandung Regency scale UMKM. With the spread of information about the products of creative industries on a scale of UMKM by making use of Geographic Information Systems (GIS), it is expected that the increase in business scale and productivity of businesses in the creative industries sector and the growing scale of UMKM will increase. The first year of this study have result output UMKM West Bandung regency profile, the profile of potential entrepreneurs creative industries UMKM, profile business potential of creative industries and design model for information dissemination potential of creative industries.
\end{abstract}

Keywords: Creative industries; UMKM; distribution of information; Geographic Information Systems (GIS).

\section{PENDAHULUAN}

Perkembangan usaha yang dilakukan oleh masyarakat tentunya harus didukung oleh beberapa faktor, mulai dari kondisi usaha, cuaca, sampai dengan teknologi.Kurangnya informasi kepada masyarakat umum tentang potensi industri kreatif pada skala UMKM yang dimiliki di Kabupaten Bandung Barat mengakibatkan pertumbuhan ekonomi kurang meningkat secara signifikan sehingga peningkatan pendapatan bagi para UMKM sulit berkembang.Dengan demikian, kebutuhan sistem informasi sangat diperlukan bagi industri kreatif skala UMKM di Kabupaten Bandung. Perkembangan persaingan global menuntut percepatan informasi ke masyarakat untuk tertarik berinvestasi atau berkunjung ke wilayah Kabupaten Bandung Barat. Sebagaimana diungkapkan dalam RPJM 2013-2018 Kabupaten Bandung bahwa permasalahan utama diantarnya adalah daya saing IKM yang belum kuat, pengembangan belum komprehensif dan berkelanjut- an serta teknologi masih kurang. Dengan persebaran informasi mengenai produk industri kreatif pada skala UMKM dengan memanfaatkan Sistem Informasi Geografis (SIG), maka diharapkan peningkatan skala usaha dan produktivitas usaha di sektor industri kreatif skala UMKM akan berkembang dan meningkat. Pada gilirannya jika usaha berkembang akan meningkatkan pendapatan, sehingga daya beli meningkat di samping kaitannya dengan penyerapan tenaga kerja yang pada akhirnya akan membantu dalam upaya menanggulangi memecahkan permasalahan penduduk di Kabupaten Bandung Barat. Dengan demikian kemiskinan dan pengangguran dapat lebih tereliminasi sehingga lebih dapat meningkatkan pendapatan masyarakat yang pada akhirnya akan lebih meningkatkan Pendapatan Asli Daerah Kabupaten Bandung Barat.

Kabupaten Bandung Barat adalah sebuah kabupaten baru di provinsi Jawa Barat yang dibentuk tahun 2007 sebagai hasil pemekaran dari Kabupaten Bandung. Kabupaten Bandung Barat memiliki 
potensi alam dan potensi ekonomi yang memberikan kontribusi cukup besar terhadap perkembangan perekonomian daerah maupun nasional. Dalam RPJM 2813-2018 Kabupaten Bandung Barat diungkapan isu strategis permasahan utama di bidang industry adalah: 1. Daya saing produk IKM belum kuat; 2. Penggunaan bahan baku lokal belum optimal dan tergantung bahan baku/penolong impor; 3. Sistem pengembangan industri/usaha mikro, kecil dan menengah belum komprehensif dan berkelanjutan; 4 . Belum optimalnya peningkatan kualitas produk melalui standarisasi dan sertifikasi produk serta perlindungan hak atas kekayaan intelektual (HAKI); 5.Kemampuan teknologi IKM masih kurang.

Perkembangan usaha yang dilakukan oleh masyarakat tentunya harus didukung oleh beberapa faktor, mulai dari kondisi usaha, cuaca, sampai dengan teknologi yang digunakan. Apabila terdapat permasalahan pada salah satu faktor pendukung, maka usaha-usaha yang telah dilakukan oleh masyarakat tidak akan berkembang dengan baik. Sistem Informasi Geografis adalah gabungan dari Sistem Informasi dan ilmu geografi Tujuan pokok dari pemanfaatan Sistem Informasi Geografis adalah untuk mempermudah mendapatkan informasi yang telah diolah dan tersimpan sebagai atribut suatu lokasi atau obyek.

Berdasarkan fenomena di atas, maka model persebaran informasi mengenai potensi industri kreatif pada skala Usaha Mikro Kecil dan Menengah (UMKM) sangat diperlukan di Kabupaten Bandung Barat. Dengan meningkatnya persebaran informasi mengenai produk industri kreatif yang dipadukan dengan UMKM dengan memanfaatkan Sistem Informasi Geografis (SIG), maka diharapkan peningkatan skala usaha dan produktivitas usaha di sektor industri kreatif UMKM akan berkembang dan meningkat.

Berdasarkan pendahuluan yang telah dijelaskan di bab sebelumnya, maka dapat dirumuskan tujuan khusus dalam penelitian ini adalah:

1. Memperoleh profil UMKM di Kabupaten Bandung Barat.

2. Memperoleh profil potensi pelaku usaha industri kreatif skala UMKM di Kabupaten Bandung Barat.

3. Memperoleh profil potensi usaha industri kreatif skala UMKM di Kabupaten Bandung Barat.

4. Menganalisis model rancangan yang tepat mengenai penyebaran informasi potensi industri kreatif skala UMKM di Kabupaten Bandung Barat.

Metode yang digunakan dalam studi ini adalah Metode Deskriptif Komparatif. Teknik studi menggunakan 3 pendekatan, yaitu (1) Studi pustaka (Desk
Studi); (2) Pendekatan Participatory Rural Appraisal (PRA), Focus Group Discusion (FGD) dan (3) Survey (wawancara dan observasi). Pelaksanaan kegiatan ini menggunakan berbagai tahap, mulai dari tahap penyusunan desain studi, penyusunan instrument, penarikan sampel (sampling technic), pengumpulan data lapangan, tabulasi data, pemilihan dan pemilahan data, analisis data, dan intrepretasi data serta penyusunan rekomendasi dan penyusunan laporan. Sedangkan metode analisis data dalam pembuatan perangkat lunak sistem informasi geografis menggunakan paradigma perangkat lunak secara waterfall.

\section{LANDASAN TEORI}

\section{Industri Kreatif}

Industri kreatif merupakan industri yang berasal dari pemanfaatan kreativitas, ketrampilan serta bakat individu untuk menciptakan kesejahteraan serta lapangan pekerjaan melalui penciptaan dan pemanfaatan daya kreasi dan daya cipta individu tersebut (Departemen Perdagangan Republik Indonesia, 2007).

Pemerintah Republik Indonesia melalui Kementerian Pariwisata dan Ekonomi Kreatif telah mengidentifikasi lingkup industri kreatif mencakup 15 subsektor. Subsektor tersebut yaitu periklanan, arsitektur, pasar barang seni, kerajinan, desain, fashion, video, film dan fotografi, permainan interaktif, musik, seni pertunjukan, penerbitan dan pencetakan, layanan komputer dan piranti lunak, broadcasting, riset dan pengembangan, dan yang terakhir adalah kuliner.

\section{UMKM}

Usaha Mikro Kecil dan Menengah (UMKM), menurut Undang-Undang No. 20 tahun 2008 tentang Usaha Mikro, Kecil dan Menengah adalah:

1. Usaha Mikro adalah usaha produktif milik orang perorangan dan/atau badan usaha perorangan yang memenuhi kriteria Usaha Mikro sebagaimana diatur dalam Undang-Undang ini.

2. Usaha Kecil adalah usaha ekonomi produktif yang berdiri sendiri, yang dilakukan oleh orang perorangan atau badan usaha yang bukan merupakan anak perusahaan atau bukan cabang perusahaan yang dimiliki, dikuasai, atau menjadi bagian baik langsung maupun tidak langsung dari Usaha Menengah atau Usaha Besar yang memenuhi kriteria Usaha kecil sebagaimana dimaksud dalam Undang-Undang ini.

3. Usaha Menengah adalah usaha ekonomi produktif yang berdiri sendiri, yang dilakukan oleh orang perorangan atau badan usaha yang bukan 
merupakan anak perusahaan atau cabang perusahaan yang dimiliki, dikuasai, atau menjadi bagian baik langsung maupun tidak langsung dengan Usaha Kecil atau Usaha Besar dengan jumlah kekayaan bersih atau hasil penjualan tahunan sebagaimana diatur dalam UndangUndang.

Menurut Undang-Undang No. 20 tahun 2008 tentang Usaha Mikro, Kecil dan Menengah adalah; (1) Kriteria Usaha Mikro adalah sebagai berikut:

a. Memiliki kekayaan bersih paling banyak $\mathrm{Rp}$ 50.000.000,00 (lima puluh juta rupiah) tidak termasuk tanah dan bangunan tempat usaha; atau

b. Memiliki hasil penjualan tahunan paling banyak Rp. 300.000.000,00 (tiga ratus juta rupiah).

(2) Kriteria Usaha Kecil adalah sebagai berikut:

a. Memiliki kekayaan bersih lebih dari Rp.50.000.000,00 (lima puluh juta rupiah) sampai dengan paling banyak Rp 500.000.000,00 (lima ratus juta rupiah) tidak termasuk tanah dan bangunan tempat usaha; atau

b. Memiliki hasil penjualan tahunan lebih dari Rp 300.000.000,00 (tiga ratus juta rupiah) sampai dengan paling banyak Rp 2.500.000.000,00 (dua milyar lima ratus juta rupiah).

(3) Kriteria Usaha Menengah adalah sebagai berikut:

a. Memiliki kekayaan bersih lebih dari Rp 500.000.000,00 (lima ratus juta rupiah) sampai dengan paling banyak Rp10.000.000.000,00 (sepuluh milyar rupiah) tidak termasuk tanah dan bangunan tempat usaha; atau

b. Memiliki hasil penjualan tahunan lebih dari Rp 2.500.000.000,00 (dua milyar lima ratus juta rupiah) sampai dengan paling banyak Rp 50.000.000.000,00 (lima puluh milyar rupiah).

\section{Sistem Informasi Geografis}

Beberapa defenisi dari SIG adalah:

1. Menurut David W. Rhind, "SIG adalah sistem komputer untuk mengumpulkan, memeriksa, mengintegrasikan, dan menganalisis informasi yang berhubungan dengan permukaan bumi”.

2. Menurut Purwadhi:

a. SIG merupakan suatu sistem yang mengorganisir perangkat keras (hardware), perangkat lunak (software), dan data, serta dapat mendayagunakan sistem penyimpanan, pengolahan, maupun analisis data secara simultan, sehingga dapat diperoleh informasi yang berkaitan dengan aspek keruangan.

b. SIG merupakan manajemen data spasial dan nonspasial yang berbasis computer dengan tiga karakteristik dasar, yaitu: (i) mempunyai fenomena aktual (variabel data nonlokasi) yang berhubungan dengan topik permasalahan di lokasi bersangkutan; (ii) merupakan suatu kejadian di suatu lokasi; dan (iii) mempunyai dimensi waktu.

\section{HASIL DAN PEMBAHASAN}

\section{Kondisi Geografis}

Wilayah Kabupaten Bandung Barat secara geografis terletak pada diantara $107^{\circ} 1,10^{\prime}$ sampai dengan $107^{\circ} 4,40^{\prime}$ Bujur Timur dan $6^{\circ} 3,73$ sampai dengan $7^{\circ} 1,031$ Lintang Selatan, dengan luas wilayah $1.305,77 \mathrm{Km} 2$ atau 130.577 ha.

Berdasarkan posisi geografisnya, Kabupaten Bandung Barat terletak diantara Kabupaten atau Kota lain yang relatif telah berkembang, yaitu Kabupaten Bandung, Kabupaten Subang, Kabupaten Purwakarta, Kabupaten Cianjur, Kota Cimahi, dan Kota Bandung. Kabupaten Bandung Barat terdiri dari 16 kecamatan. Kecamatan terluas adalah Kecamatan Gununghalu seluas $16.796,2$ ha $(12,29 \%)$ dan terkecil adalah Kecamatan Ngamprah seluas 3,608 ha (2,76\%). Luas kecamatan dan jumlah desa di Kabupaten Bandung Barat tertera pada tabel di bawah.

\section{Rekapitulasi Data UMKM Kabupaten Bandung Barat}

Berdasarkan tabel 1 didapatkan informasi bahwa jenis usaha yang paling banyak terdapat dalam UMKM di Kabupaten Bandung Barat yaitu jenis usaha mikro, kemudian usaha kecil dan yang terakhir adalah jenis usaha menengah. Begitu juga apabila dilihat dari jumlah tenaga kerja yang ada, jenis usaha mikro mempunyai jumlah yang paling banyak untuk kemudian disusul oleh jenis usaha kecil dan terakhir yaitu skala menengah.

Tabel 1. Rekapitulasi Data UMKM Bandung Barat

\begin{tabular}{|l|r|}
\hline \multicolumn{1}{|c|}{ Jenis Usaha } & $\begin{array}{c}\text { Jumlah Pelaku } \\
\text { Usaha }\end{array}$ \\
\hline Mikro & 2.154 \\
\hline Kecil & 562 \\
\hline Menengah & 53 \\
\hline Total UMKM KBB & 2.769 \\
\hline
\end{tabular}


Berdasarkan tabel 2 dapat diperoleh informasi bahwa untuk skala usaha mikro, tiga besar kecamatan yang paling banyak untuk skala usaha mikro terdapat di daerah kecamatan Cihampelas, kemudian Cipongkor dan Padalarang. Kemudian yang paling sedikit untuk skala mikro yaitu daerah kecamatan saguling.

Untuk skala usaha kecil di daerah Kabupaten Bandung Barat, paling banyak terdapat di daerah kecamatan Padalarang, kemudian Cipatat dan yang ketiga terbanyak adalah kecamatan Lembang. Sedangkan daerah yang paling sedikit untuk skala usaha kecil adalah daerah kecamatan rongga, sindang kerta dan kecamatan saguling.

Untuk skala usaha menengah di daerah Kabupaten Bandung Barat, paling banyak ditemui yaitu di daerah kecamatan Cipeundeuy, kemudian kecamatan Cihampelas dan yang ketiga terbanyak adalah kecamatan Cipongkor. Sedangkan daerah yang paling sedikit untuk skala menengah yaitu daerah Kecamatan Gunung Halu.

Apabila dilihat dari total jumlah UMKM yang ada di Kabupaten Bandung Barat, urutan pertama daerah yang mempunyai jumlah UMKM yang banyak yaitu urutan pertama Kecamatan Cihampelas, kedua yaitu Kecamatan Cipongkor, dan urutan ketiga yaitu Kecamatan Cipeundeuy. Sedangkan daerah yang paling sedikit jumlah UMKM nya adalah daerah kecamatan Sindang Kerta, Gunung Halu dan yang terakhir adalah Saguling.

Tabel 2. Rekapitulasi Data UMKM Bandung Barat Berdasarkan Skala Usaha

\begin{tabular}{|c|c|c|c|c|c|}
\hline \multirow{2}{*}{ No } & \multirow{2}{*}{ Kecamatan } & \multicolumn{4}{|c|}{$\begin{array}{l}\text { Jumlah Perusahaan Berdasarkan } \\
\text { Skala Usaha }\end{array}$} \\
\hline & & Mikro & Kecil & Menengah & $\begin{array}{l}\text { Total } \\
\text { UMKM }\end{array}$ \\
\hline 1 & Batujajajar & 59 & 1 & 13 & 73 \\
\hline 2 & $\begin{array}{l}\text { Cikalong } \\
\text { Wetan }\end{array}$ & 63 & 5 & 13 & 81 \\
\hline 3 & Cihampelas & 459 & 1 & 55 & 515 \\
\hline 4 & Cililin & 136 & 0 & 16 & 152 \\
\hline 5 & Cipatat & 78 & 14 & 40 & 132 \\
\hline 6 & Cipendeuy & 158 & 0 & 210 & 368 \\
\hline 7 & Cipongkor & 374 & 2 & 51 & 427 \\
\hline 8 & Cisarua & 49 & 3 & 8 & 60 \\
\hline 9 & $\begin{array}{l}\text { Gunung } \\
\text { Halu }\end{array}$ & 13 & 0 & 1 & 14 \\
\hline 10 & Lembang & 175 & 6 & 39 & 220 \\
\hline 11 & Ngamprah & 202 & 2 & 48 & 252 \\
\hline 12 & Padalarang & 215 & 17 & 34 & 266 \\
\hline 13 & Parongpong & 57 & 2 & 21 & 80 \\
\hline 14 & Rongga & 103 & 0 & 4 & 107 \\
\hline 15 & $\begin{array}{l}\text { Sindang } \\
\text { Kerta }\end{array}$ & 12 & 0 & 7 & 19 \\
\hline 16 & Saguling & 1 & 0 & 2 & 3 \\
\hline & Total & 2.154 & 53 & 562 & 2.769 \\
\hline
\end{tabular}

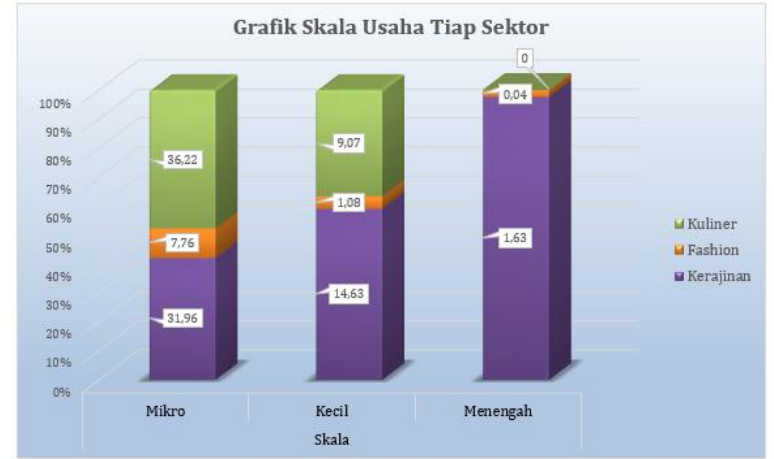

Gambar 1. Skala Usaha UMKM Tiap Sektor

Berdasarkan dari penjelasan Gambar 1, dapat disimpulkan bahwa UMKM yang ada di Kabupaten Bandung Barat terdiri dari skala Mikro, Kecil dan Menengah. Dari data tersebut dapat diketahui ada tiga sektor usaha yang tidak ditemukan di Kabupaten Bandung Barat, yaitu Arsitektur, Desain, serta Televisi \& Radio dimana baik dari skala mikro, kecil dan menengah untuk ketiga usaha tersebut nilanya 0 atau tidak ditemukan.

Ada tiga sektor industri kreatif yang mempunyai potensi usaha paling besar yaitu urutan pertama adalah sektor industri kerajinan, kemudian urutan kedua adalah kuliner dan ketiga adalah fashion.Ketiga industri kreatif tersebut tersebar kedalam tiga skala UMKM yaitu kecil, menengah dan mikro.

Bagi skala UMKM mikro, diketahui bahwa industri kreatif yang paling banyak adalah kuliner sebanyak $36,22 \%$, diikuti dengan industri kreatif kerajinan sebesar 31,96 persen dan indistri kreatif fashion sebesar 31,96\%. Untuk skala UMKM kecil, dapat diketahui bahwa industri kreatif yang paling banyak adalah industri kerajinan yaitu sebanyak $14,64 \%$, diikuti oleh kuliner sebanyak 9,07\% serta industri fashion sebesar $1,08 \%$. Sedangkan untuk skala UMKM menengah, sektor industri kreatif yang paling mendominasi adalah kerajinan dan fashion.

Apabila dilihat dari informasi yang ada tabel 5.4, dapat diketahui bahwa untuk industri kreatif sektor kerajinan, paling banyak terdapat didaerah Kecamatan Cihampelas, Kecamatan Cipeundeuy, dan Kecamatan Cipongkor. Sedangkan industri kerajinan yang paling sedikit ditemui di daerah kecamatan Saguling. Berdasarkan informasi tersebut, maka dapat diperoleh informasi bahwa Kecamatan Cihampelas, Cipeundeuy dan Cipongkor bisa dikatakan mempunyai potensi usaha industri kreatif di sektor kerajinan yang sangat tinggi.

Untuk sektor usaha industri kreatif kuliner, paling banyak terdapat di daerah Kecamatan Cipongkor, kemudian Kecamatan Cihampelas dan Kecamatan Lembang.Sedangkan industri kreatif 
kuliner yang paling sedikit ditemui di kecamatan Saguling. Berdasarkan informasi tersebut, maka dapat diperoleh informasi bahwa kecamatan Cipongkor, Cihampelas dan Kecamatan Lembang bisa dikatakan mempunyai potensi usaha industri kreatif di sektor kuliner yang sangat tinggi.

Untuk sektor usaha industri kreatif fashion, paling banyak terdapat didaerah Kecamatan Padalarang, kemudian Kecamatan Ngamprah dan kecamatan Cipeundeuy.Sedangkan industri kreatif fashion yang paling sedikit ditemui di Kecamatan Saguling. Berdasarkan informasi tersebut, maka dapat diperoleh informasi bahwa kecamatan Padalarang, Ngamprah dan Cipeundeuy bisa dikatakan mempunyai potensi industri kreatif di sektor fashion yang sangat tinggi.

Berdasarkan hasil analisis data yang diperoleh, dapat diketahui juga bahwa Kecamatan Saguling merupakan kecamatan yang memiliki potensi industri kreatif sangat rendah untuk sektor industri kerajinan, kuliner dan fashion.

\section{Analisis Rancangan Sistem Persebaran Informasi Industri Kreatif}

Adapun permasalahan yang didapatkan setelah melakukan survey kepada masyarakat, maka dapat diperoleh masalah utama yaitu sulit dan lamanya waktu yang diperlukan oleh pengguna atau masyarakat untuk memperoleh data sebaran industri UMKM, karena belum adanya media atau informasi yang dapat membantu memberikan informasi tersebut. Hal tersebut tentunya dapat menghambat para investor atau masyarakat untuk menanamkan investasinya di daerah Kabupaten Bandung Barat.

\section{Rancangan Arsitektur Sistem Yang akan Dibangun}

Adapun analisis arsitektur dari sistem informasi geografis persebaran industri kreatif UMKM di Kab. Bandung Barat dapat dilihat pada gambar berikut:

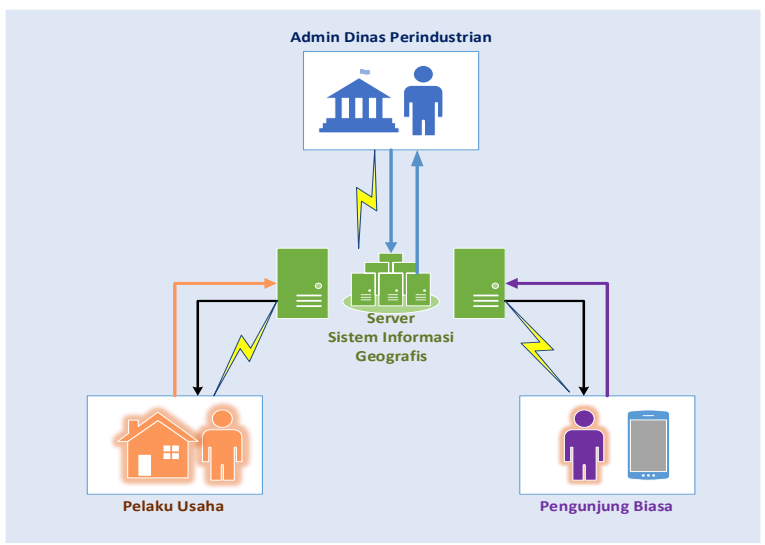

Gambar 2. Arsitektur Sistem yang akan Dibangun

\section{Rancangan Pengguna Sistem}

Detail penjelasan pengguna dalam sistem informasi persebaran industri kreatif UMKM di Kab. Bandung Barat adalah sebagai berikut:

1. Admin

Pengguna sistem yang bertindak sebagai Admin merupakan seorang pegawai di Dinas Perindustrian dan Perdagangan Kabupaten Bandung Barat. Adapun tanggung jawab yang ada pada pengguna seorang Admin yaitu:

- Melakukan pengolahan data mengenai industri UMKM di Kab. Bandung Barat

- Melakukan pengolahan data pelaku usaha UMKM di Kab. Bandung Barat

- Melakukan pengolahan data admin.

2. Pengusaha/Pelaku Usaha

Pengguna sistem yang bertindak sebagai Pelaku Usaha merupakan masyarakat yang mempunyai usaha industri kreatif UMKM di Kab.Bandung Barat. Adapun tanggung jawab yang ada pada pengguna seorang Pelaku Usaha yaitu:

- Melakukan pengolahan data mengenai industri UMKM yang dimiliki

- Melakukan pengolahan data pelaku usaha

3. Pengunjung Biasa

Pengguna sistem yang bertindak sebagai Pengunjung Biasa merupakan masyarakat yang mengakses sistem hanya untuk melihat persebaran informasi mengenai industri UMKM yang ada di Kab. Bandung Barat. Pengunjung Biasa tidak akan bisa login kedalam sistem.

\section{Analisis Diagram Konteks Sistem}

Diagram konteks merupakan diagram yang terdiri dari suatu proses dan menggambarkan ruang lingkup suatu sistem. Adapun diagram konteks untuk sistem yang akan dibangun dapat dilihat pada gambar berikut:

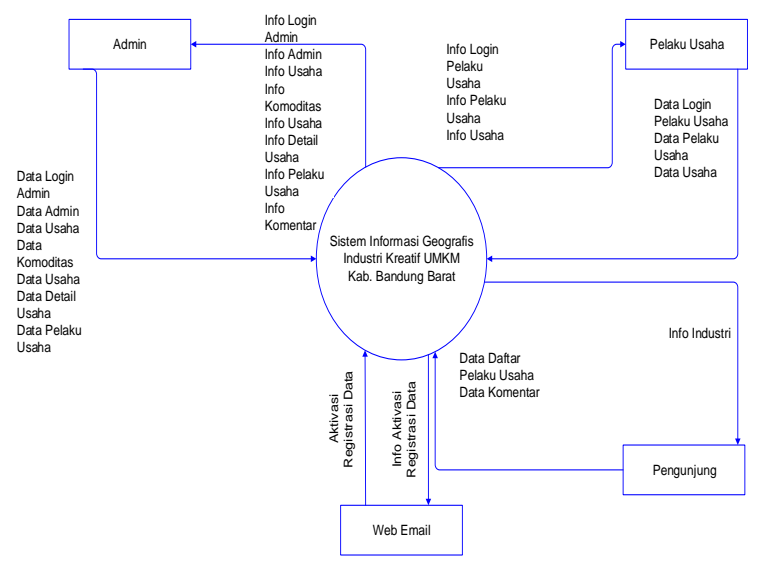

Gambar 3. Rancangan Diagram Konteks Sistem 


\section{Rancangan Struktur Menu Pelaku Usaha}

Berikut ini merupakan rancangan struktur menu Pelaku Usaha dari sistem yang akan dibangun.

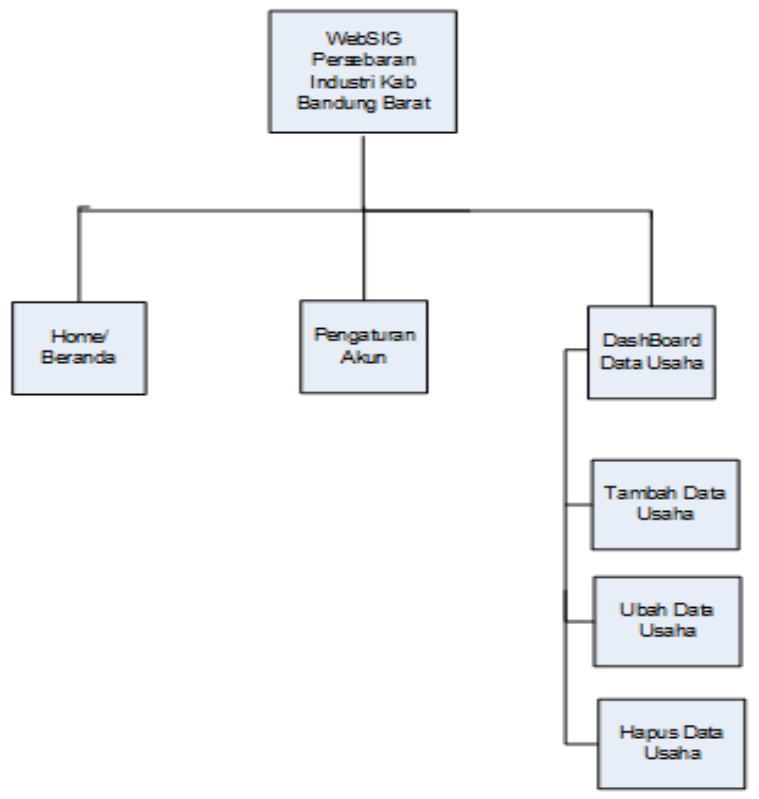

Gambar 4.Rancangan Struktur Menu Admin Dinas

\section{Rancangan Struktur Menu Admin}

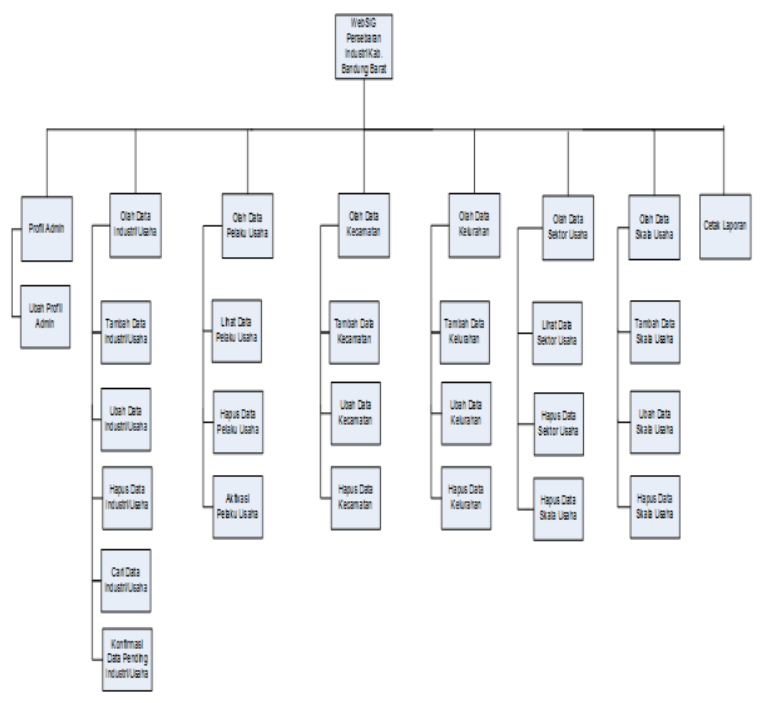

Gambar 5. Rancangan Struktur Menu Admin

Rancangan struktur menu Admin dari sistem yang akan dibangun dapat dilihat pada Gambar 5 .

\section{Model Rancangan Tampilan Halaman Dash- board Pelaku Usaha}

Perancangan tampilan antarmuka halaman dashboard pelaku usaha setelah berhasil login. Rancangan tampilannya adalah sebagai berikut:

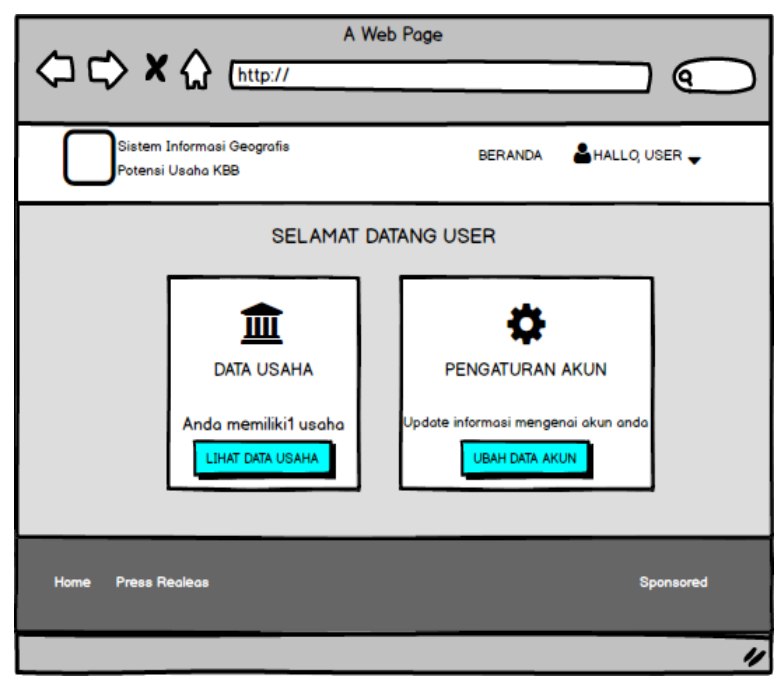

Gambar 6. Rancangan Tampilan Dashboard Pelaku Usaha

\section{Model Rancangan Tampilan Halaman Dash-} board Admin Dinas

Tampilan ini akan tampil setelah admin dinas berhasil login. Admin Dinas setelah berhasil login dapat melihat statistik data, melakukan pengolahan data wilayah kecamatan dan kelurahan, pengolahan data skala, data sektor, data usaha, serta mencetak laporan. Rancangan tampilannya adalah sebagai berikut:

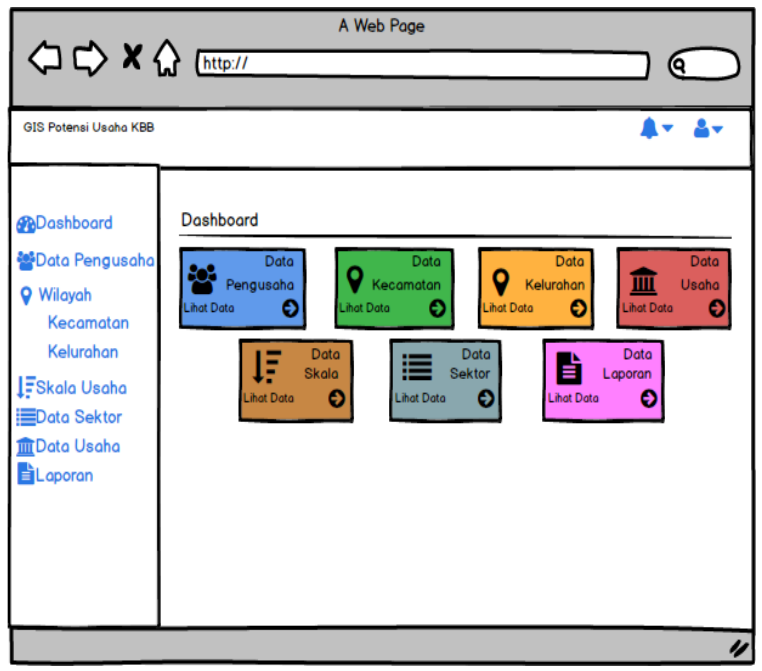

Gambar 7. Model Rancangan Antarmuka Tampilan Dashboard Admin Dinas

\section{Model Rancangan Tampilan Halaman Utama Pengunjung}

Perancangan antarmuka halaman utama merupakan tampilan pertama yang akan muncul saat mengakses sistem SIG Persebaran Industri Kreatif Kabupaten Bandung Barat. Perancangan antarmuka halaman utama dapat dilihat pada gambar berikut: 


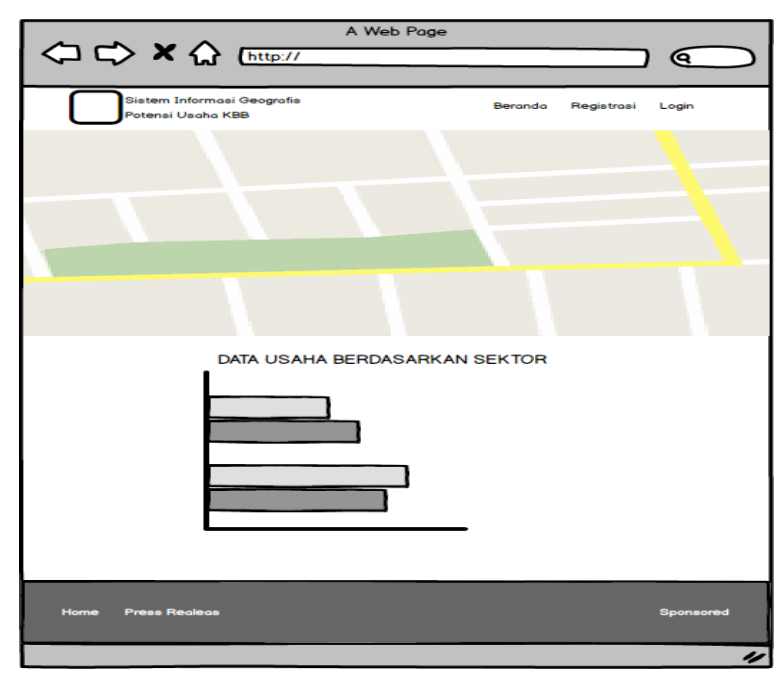

Gambar 8. Model Rancangan Antarmuka Halaman Pengunjung

\section{SIMPULAN}

Berdasarkan penelitian yang telah dilakukan maka dapat diambil beberapa kesimpulan, yaitu:

1. Berdasarkan letak geografis UMKM di Kabupaten Bandung Barat tersebar kedalam 16 kecamatan dan 165 Desa.

2. Berdasarkan profil potensi pelaku usaha didapatkan informasi untuk usia, bisa dikatakan persentasenya cukup merata dari usia 0-35 tahun sampai dengan 66-70 tahun. Namun demikian, dapat diperoleh informasi bahwa para pelaku industri kreatif UMKM di Kab. Bandung Barat masih banyak yang berusia muda.

3. Berdasarkan penelitian yang telah dilakukan dapat disimpulkan bahwa ada tiga sektor industri kreatif yang mempunyai potensi usaha paling besar. Urutan pertama adalah sektor industri kreatif kerajinan, kedua adalah industri kuliner, dan ketiga adalah fashion.
4. Telah didapatkan rancangan sistem untuk memodelkan potensi industri kreatif skala UMKM dengan memanfaatkan konsep Sistem Informasi Geografis (SIG).

\section{DAFTAR PUSTAKA}

Anep Paoji, 2014, Kendala Industri Kreatif Mirip UKM, bisnis.com jawa barat, Sabtu, 12 April 2014,ttp://www.pikiran-rakyat.com/node/261375

Husein, Rahmad. 2006. Konsep Dasar Sistem Informasi Geografis.

Eli Komara, 2012, Usaha Kreatif Dongkrak Perekonomian Jabar, http://dispenda-jabar.blogspot. com/2012/03/usaha-kreatif-dongkrak-perekonomian.html, <27/04/2014>

Puguh Setyo Nugroho, Malik Cahyadin, 2014, Analisis Perkembangan Industri Kreatif di Indonesia, hal. 1-20,

Rachmaona, 2009, Ancaman Persaingan Ekonomi Kreatif Terhadap Nasionalisme Bangsa, 9 Oktober,http://rachmaona.wordpress.com/2009/10/14/a ncaman-persaingan-ekonomi-kreatif-terhadapnasionalisme-bangsa/, <27/04/2014>

Turban, Leidner, McLean, and Wetherbe, Information Technology for Management, 6th ed.: John Wiley \& Sons (Asis) Pte Ltd, 2008.

Jogiyanto, Analisis dan Desain Sistem Informasi. Yogyakarta: Andi Offset, 2005.

William H DeLone, Ephraim R. McLean, The DeLone and McLean Model of Information Systems Success: A Teen-Year Update, Journal of Management Information System, vol. 19, pp. 9-30, 2003.

Sugiyono, Metoda Penelitian Kuantitatif dan Kualitatif, Bandung: Alfabeta, 2011.

Sommerville. 2001. Software Engineering (9th Edition). USA: Pearson Education 